\title{
Adult attractiveness and oviposition preference of Zabrotes subfasciatus toward genotypes of common bean Phaseolus vulgaris
}

\author{
Elio C. Guzzo (D) José D. Vendramim • \\ André L. Lourenção • Alisson F. Chiorato • \\ Sérgio A. M. Carbonell • Osvaldo M. B. Corrêa
}

Received: 15 May 2018 / Accepted: 11 October 2018/Published online: 22 October 2018

(C) Springer Nature B.V. 2018

\begin{abstract}
The Mexican bean weevil Zabrotes subfasciatus (Coleoptera: Chrysomelidae: Bruchinae) is among the key pests of common bean Phaseolus vulgaris $\mathrm{L}$. around the world. Identifying resistance sources and the resistance types involved is important for development of pest-resistant bean varieties. This study assessed the adult attractiveness and oviposition preference of $Z$. subfasciatus toward eight genotypes of common bean, including seven pre-selected resistant genotypes and one standard for susceptibility. Attraction to the genotypes was assessed at one and four days after infestation. Oviposition preference was tested under free- and no-choice (confinement) conditions. We observed that IAC 853 was the least oviposited genotype in the free-choice test. However, this finding was not confirmed by the no-choice test. Therefore, IAC 853 could not be characterized as resistant to $Z$. subfasciatus. Presence of the toxic protein arcelin does not appear to influence host selection by $Z$. subfasciatus.
\end{abstract}

E. C. Guzzo $(\bowtie)$

Embrapa Tabuleiros Costeiros, Av. Beira Mar n 3.250, Bairro Jardins, Aracaju, SE 49025-040, Brazil

e-mail: elio.guzzo@embrapa.br

J. D. Vendramim

Depto de Entomologia e Acarologia, Escola Superior de

Agricultura 'Luiz de Queiroz', Piracicaba, SP, Brazil

A. L. Lourenção · A. F. Chiorato · S. A. M. Carbonell Instituto Agronômico (IAC), Campinas, SP, Brazil

O. M. B. Corrêa

Universidade Metodista de Piracicaba (UNIMEP), Piracicaba, SP, Brazil
Keywords Host plant resistance · Host selection · Antixenosis · Non-preference $\cdot$ Chrysomelidae . Bruchinae

\section{Introduction}

The Mexican bean weevil Zabrotes subfasciatus (Boheman) (Coleoptera: Chrysomelidae: Bruchinae) is native to Central and South America, where it is an important pest of common bean (Phaseolus vulgaris L.). However, it has disseminated worldwide and became a major global pest of bean crops. Zabrotes subfasciatus is commonly found in tropical and subtropical regions, including Africa, Southeast Asia, India, the Mediterranean, and parts of Europe (Athié and Paula 2002; Hill 2002). In Brazil, this species is also present in all bean-growing states, particularly in the states of Amazonas, Bahia, Espírito Santo, Pará, Rio de Janeiro, Rio Grande do Sul, and São Paulo (Silva et al. 1968).

When adult females oviposit, they produce an adhesive secretion that they use to affix their eggs to the integument of bean grains. Newly emerged larvae move directly from the egg into the interior of the grain, using the chorion for support and not having contact with the exterior environment. Infestation can begin during bean storage or in the field. In the latter case, weevil larvae are carried into warehouses while already inside the seeds, in which they feed on the cotyledons and may destroy them completely. Bean infestation by $Z$. subfasciatus can be initially detected when eggs are observed fixed to the integument of bean seeds, or upon observation of 
adults and their exit holes, or of opercula (Athié and Paula 2002; Hill 2002).

Bruchinae in stored beans are normally controlled via insecticide spraying onto the grains or by fumigation. The latter method is favored due to the size of the seeds and the existing gaps between them (Hill 2002), although the use of more environmentally safe methods should be encouraged. Resistant plant varieties are a pest control method that does not cause environmental disturbance or pollution, does not leave residue on foodstuffs, requires no specific knowledge from the grower, offers continuous action against pests, and is consistent with the philosophy of Integrated Pest Management (Norris et al. 2003; Vendramim and Guzzo 2009, 2012).

Host plant resistance is usually classified as either antixenosis (or non-preference), antibiosis, or tolerance (Panda and Khush 1995; Smith 2005; Vendramim and Guzzo 2012), and a single plant variety can exhibit more than one of these types of resistance, resulting in a complex interaction between plant and insect (Vendramim and Guzzo 2012). Some authors have reported antixenosis (Baldin et al. 2007; Ribeiro-Costa et al. 2007), antibiosis (Ribeiro-Costa et al. 2007; Baldin and Pereira 2010; Eduardo et al. 2016), and antixenosis and/or antibiosis (Boiça Jr. et al. 2002; Moraes et al. $2011)$ by genotypes of $P$. vulgaris against $Z$. subfasciatus. Tolerance-type resistance does not apply to this situation, as bean grains are the final product of a bean crop, in which the plant is no longer able to recover or compensate for damage caused by the pest. Not only can resistant varieties be immediately recommended and used by growers, but also the resistance found in wild lineages of beans can be transferred to cultivars with desirable agronomical characteristics. This can be done by backcrossing or by genetic engineering.

This study assessed the adult attractiveness and oviposition preference of $Z$. subfasciatus for eight genotypes of common bean, including seven pre-selected resistant genotypes and one susceptible control.

\section{Material and methods}

Insects and bean genotypes used

The Z. subfasciatus individuals used in the bioassays were obtained from a laboratory stock colony, reared for several generations on Bolinha bean cultivar, under uncontrolled environmental conditions. All assays were performed using insects aged 0-24 h.

Seven bean genotypes with resistance to Z. subfasciatus were used, pre-selected among 202 genotypes (Guzzo et al. 2015), in addition to the cultivar standard for susceptibility 'Bolinha' (Table 1). All genotypes were obtained from the Bean Active Germplasm Bank at the Instituto Agronômico (IAC), Campinas, SP, Brazil. All materials were multiplied simultaneously for uniformization. Harvested dry beans were stored into freezing condition of $0{ }^{\circ} \mathrm{C}$, to prevent deterioration and to eliminate potential prior infestations by any species of insect.

Table 1 Genotypes of common bean Phaseolus vulgaris used in bioassays and main characteristics of their seeds ${ }^{\mathrm{a}}$

\begin{tabular}{|c|c|c|c|c|c|}
\hline \multirow[t]{2}{*}{ Accession $^{\mathrm{b}}$} & \multirow[t]{2}{*}{ Genotype name } & \multicolumn{4}{|l|}{ Seed } \\
\hline & & Main color & Shape & Flatness & Brilliance \\
\hline IAC 570 & MD-806 & Cream & Oval/Kidney shaped & Semi-flat & Dull \\
\hline IAC $583^{\mathrm{c}}$ & ARC-1 & Black & Oval & Flat & Dull \\
\hline IAC $584^{\mathrm{c}}$ & ARC-2 & Black & Oval & Flat & Shiny \\
\hline IAC 610 & Oito e Nove & Black & Short Oval/Kidney shaped & Flat & Dull \\
\hline IAC $816^{\mathrm{c}}$ & RAZ-49 & Black & Short Oval/Kidney shaped & Flat & Dull \\
\hline $\mathrm{IAC} 818^{\mathrm{c}}$ & RAZ-59 & Black & Oval & Semi-flat & Dull \\
\hline IAC $819^{c}$ & RAZ-55 & Black & Oval & Semi-flat & Dull \\
\hline IAC 853 & Bolinha CB & Yellow & Round & Full & Shiny \\
\hline
\end{tabular}

${ }^{\mathrm{a}}$ As classified by Brasil (2006)

${ }^{\mathrm{b}}$ Bean Active Germplasm Bank, IAC

${ }^{c}$ Arcelin-carrying genotype 
Attractiveness and oviposition in free-choice test

Circular aluminum arenas $(35 \mathrm{~cm}$ inner diameter, $5 \mathrm{~cm}$ height) were used, each containing a polystyrene sheet of the same diameter and $2 \mathrm{~cm}$ thickness. Eight circular holes, $6 \mathrm{~cm}$ in diameter, were made along the perimeter of each sheet, equidistant among themselves and from the center (Mazzonetto and Boiça Jr. 1999). Open-top, tight-fitting plastic boxes of the same diameter and height were introduced into these holes, upper rims flush with the surface of the polystyrene sheet. Each box received $20 \mathrm{~g}$ of beans of each tested genotypes. Eighty pairs of males and females of $Z$. subfasciatus were subsequently released in the center of each arena. The arenas were enclosed with aluminum covers and kept in the laboratory. The weevils present on each genotype were counted at the first and the fourth days after infestation, with minimum disturbance of the weevils or beans. After four days, the adults were removed. After an additional 10 days, the number of eggs laid on the beans was also counted.

\section{Oviposition in no-choice test}

For each tested genotype, 20 beans were placed into a circular, clear plastic box $(6 \mathrm{~cm}$ diameter and $2 \mathrm{~cm}$ height), along with one adult couple of $Z$. subfasciatus. The weevils were kept in the boxes during $24 \mathrm{~h}$ and subsequently removed. The number of eggs laid on the beans was counted 10 days later.

\section{Microscopic observation}

The beans were kept in a desiccator with silica for one week before being dissected for integument removal. Sections of integument measuring approximately $9 \mathrm{~mm}^{2}$ were affixed to specimen mounts with carbon adhesive tape and placed in the desiccator for an additional seven days, for dehydration. After this period, the samples were coated in gold using a sputter coater (Balzers brand, model MED 010) for three minutes. After coating, the samples were viewed with a scanning electron microscope (Zeiss brand, model DSM 900).

\section{Statistical analysis}

Data from the free-choice test were submitted to the Kruskal-Wallis test $(P<0.05)$ and data from the nochoice test were submitted to a variance analysis and means compared by Tukey's test $(P<0.05)$ using the GENES Software (Cruz 2013, 2016). For both experiments, there were 12 replications per genotype, considering each genotype as one treatment and each replication composed by 20 beans.

\section{Results}

The number of adults of $Z$. subfasciatus present on the genotypes in the free-choice test showed no differences in the preference of females at the first day $(H=17.26$, $d f=7, P<0.05)$, and of the males at the fourth day $(H=$ $9.39, d f=7, P<0.05)$. However, the genotype IAC 853 was less preferred by the males at the first day $(H=$ 19.12, $d f=7, P<0.05)$ and by females in the fourth day $(H=11.16, d f=7, P<0.05)$. When considering males and females together, the genotype IAC 853 was the least preferred genotype differing from IAC 818 and IAC 816 at one day $(H=17.09, d f=7, P<0.05)$, and from IAC 819 and IAC 584 at four days $(H=19.25$, $d f=7, P<0.05$ ) after infestation (Table 2).

In regard to oviposition (Table 3 ), in the free-choice test, IAC 853 also presented the lowest number of Z. subfasciatus eggs differing $(H=21.47, d f=7$, $P<0.05)$ from IAC 610 and IAC 584, which were the most oviposited, at levels over three times higher than was observed on IAC 853 . The other genotypes showed intermediate oviposition and did not differ from the former ones in this respect. However, under no-choice (confinement) conditions, oviposition by Z. subfasciatus did not follow the same pattern observed in the free-choice test. IAC 570 was the least oviposited and some genotypes such as IAC 610, IAC 819, IAC 584 and IAC 853 presented about two times more eggs than that, but no difference was detected $(F=2.41, d f=$ $7, P<0.05)$ among the tested genotypes (Table 3 ).

\section{Discussion}

Although genotype IAC 853 was the least preferred by Z. subfasciatus, we should emphasize that the smaller number of adults found on that genotype does not reflect an antixenosis for feeding, as adults of these weevils do not use legume seeds for this purpose (Lawrence et al. 1991; Athié and Paula 2002; Hill 2002). When females of $Z$. subfasciatus oviposit, they produce an adhesive substance and use it to affix their eggs to bean seeds, as 
Table 2 Number of adults (mean \pm standard deviation) of Zabrotes subfasciatus present on genotypes of Phaseolus vulgaris at one and four days after infestation (D.A.I.), in free-choice test ${ }^{\mathrm{a}}$

\begin{tabular}{|c|c|c|c|c|c|c|}
\hline \multirow[t]{2}{*}{ Accession $^{\mathrm{b}}$} & \multicolumn{3}{|c|}{ No. of weevils 1 D.A.I. } & \multicolumn{3}{|c|}{ No. of weevils 4 D.A.I. } \\
\hline & Males & Females & Total & Males & Females & Total \\
\hline $\mathrm{IAC} 818^{\mathrm{c}}$ & $10.7 \pm 0.80 \mathrm{a}$ & $9.5 \pm 1.15 \mathrm{a}$ & $20.2 \pm 0.95 \mathrm{a}$ & $9.0 \pm 1.29 \mathrm{a}$ & $7.2 \pm 0.70 \mathrm{ab}$ & $16.2 \pm 1.76 \mathrm{ab}$ \\
\hline IAC $816^{\mathrm{c}}$ & $9.5 \pm 1.67 \mathrm{ab}$ & $9.5 \pm 1.88 \mathrm{a}$ & $19.0 \pm 1.21 \mathrm{a}$ & $8.5 \pm 1.36 \mathrm{a}$ & $7.2 \pm 1.08 \mathrm{ab}$ & $15.7 \pm 2.28 \mathrm{ab}$ \\
\hline IAC $583^{\mathrm{c}}$ & $10.3 \pm 0.67 \mathrm{a}$ & $8.2 \pm 1.33 \mathrm{a}$ & $18.5 \pm 1.75 \mathrm{ab}$ & $8.2 \pm 0.87 \mathrm{a}$ & $8.7 \pm 0.80 \mathrm{a}$ & $16.8 \pm 1.30 \mathrm{ab}$ \\
\hline IAC $819^{c}$ & $10.2 \pm 1.01 \mathrm{ab}$ & $8.0 \pm 0.68 \mathrm{a}$ & $18.2 \pm 1.22 \mathrm{ab}$ & $10.0 \pm 1.39 \mathrm{a}$ & $8.7 \pm 1.20 \mathrm{a}$ & $18.7 \pm 1.28 \mathrm{a}$ \\
\hline IAC 610 & $10.2 \pm 1.54 \mathrm{ab}$ & $7.7 \pm 0.84 \mathrm{a}$ & $17.8 \pm 2.09 \mathrm{ab}$ & $8.7 \pm 1.15 \mathrm{a}$ & $7.7 \pm 1.76 \mathrm{ab}$ & $16.3 \pm 2.72 \mathrm{ab}$ \\
\hline IAC $584^{\mathrm{c}}$ & $7.5 \pm 1.06 \mathrm{ab}$ & $9.2 \pm 0.91 \mathrm{a}$ & $16.7 \pm 1.12 \mathrm{ab}$ & $8.8 \pm 0.87 \mathrm{a}$ & $8.8 \pm 1.49 \mathrm{a}$ & $17.7 \pm 2.08 \mathrm{a}$ \\
\hline IAC 570 & $9.2 \pm 1.08 \mathrm{ab}$ & $6.7 \pm 2.11 \mathrm{a}$ & $15.8 \pm 2.43 \mathrm{ab}$ & $6.3 \pm 0.88 \mathrm{a}$ & $5.0 \pm 1.29 \mathrm{ab}$ & $11.3 \pm 0.80 \mathrm{ab}$ \\
\hline IAC 853 & $4.0 \pm 0.89 \mathrm{~b}$ & $6.0 \pm 0.68 \mathrm{a}$ & $10.0 \pm 0.78 \mathrm{~b}$ & $5.5 \pm 0.67 \mathrm{a}$ & $2.3 \pm 0.56 \mathrm{~b}$ & $7.8 \pm 0.60 \mathrm{~b}$ \\
\hline$H$ & 17,26 & 9,39 & 19,12 & 11,16 & 17,09 & 19,25 \\
\hline
\end{tabular}

${ }^{a}$ Means followed by the same letter in the same column are not significantly different by Kruskal-Wallis test $(P \leq 0.05)$

${ }^{\mathrm{b}}$ Bean Active Germplasm Bank, IAC

${ }^{\mathrm{c}}$ Arcelin-carrying genotype

opposed to simply depositing eggs at random on the substrate. This leads to the assumption that adult Mexican bean weevils preserve the characteristic of host selection for oviposition (Parsons and Credland 2003), differently from species whose larvae are able to move in search of the most suitable host.

Bernays and Chapman (1994) didactically divide the process of host selection by phytophagous insects into

Table 3 Number of eggs (mean \pm standard deviation) of Zabrotes subfasciatus on grains of different genotypes of Phaseolus vulgaris, in free-choice and no-choice tests

\begin{tabular}{|c|c|c|}
\hline \multirow[t]{2}{*}{ Accession $^{\mathrm{a}}$} & \multicolumn{2}{|l|}{ No. of eggs } \\
\hline & Free-choice test $\mathrm{t}^{\mathrm{b}}$ & No-choice test ${ }^{\mathrm{c}}$ \\
\hline IAC 610 & $237.5 \pm 24.18 \mathrm{a}$ & $13.8 \pm 2.93$ \\
\hline IAC $584^{\mathrm{d}}$ & $233.3 \pm 29.98 \mathrm{a}$ & $10.3 \pm 2.06$ \\
\hline IAC $816^{\mathrm{d}}$ & $209.5 \pm 21.61 \mathrm{ab}$ & $6.2 \pm 1.66$ \\
\hline IAC $819^{d}$ & $200.2 \pm 30.46 \mathrm{ab}$ & $10.5 \pm 2.28$ \\
\hline IAC 570 & $197.0 \pm 19.53 \mathrm{ab}$ & $5.5 \pm 0.89$ \\
\hline IAC $583^{d}$ & $166.5 \pm 16.35 \mathrm{ab}$ & $6.8 \pm 0.79$ \\
\hline IAC $818^{\mathrm{d}}$ & $110.8 \pm 26.64 \mathrm{ab}$ & $6.8 \pm 1.96$ \\
\hline \multirow[t]{2}{*}{ IAC 853} & $71.8 \pm 15.74 \mathrm{~b}$ & $10.0 \pm 1.13$ \\
\hline & $H=21,47$ & $F=2,41$ \\
\hline
\end{tabular}

${ }^{\mathrm{a}}$ Bean Active Germplasm Bank, IAC

${ }^{\mathrm{b}}$ Means followed by the same letter in the same column are not significantly different by Kruskal-Wallis test $(P \leq 0.05)$

${ }^{\mathrm{c}}$ Means were not significantly different by Tukey's test $(P \leq 0.05)$

${ }^{\mathrm{d}}$ Arcelin-carrying genotype different stages, stating that insects use visual cues in the final stage of approach, some of the most important being color, shape and contrast of the host plant in relation to the surrounding environment. In light of this, the distribution of weevils among genotypes assessed in this study could be explained by grain color, as the two genotypes with the lowest number of adults are light (IAC 853 is greenish yellow and IAC 570 is creamcolored), whereas all the other genotypes are black. When it comes to contrast, light-colored genotypes would contrast more strongly against the interior of the dark arena than would darker-colored genotypes. However, the extent to which $Z$. subfasciatus can distinguish color and contrast within a lightless arena is unknown. Bastos (1969), studying Callosobruchus analis (F.) (Coleoptera: Chrysomelidae: Bruchinae), and Ramalho et al. (1977), studying Acanthoscelides obtectus (Say) (Coleoptera: Chrysomelidae: Bruchinae), did not observe any influence of grain color on preference for different varieties of $P$. vulgaris.

In addition, according to Bernays and Chapman (1994), once an insect comes into contact with its host, already at the host acceptance stage, texture becomes a highly important factor in whether or not the insect will remain on the host. Nwanze et al. (1975) and Nwanze and Horber (1976) observed that the rough texture of the seed coat of different varieties of Vigna unguiculata (L.) is a determining factor for low oviposition and larval development of Callosobruchus maculatus (F.) (Coleoptera: Chrysomelidae: Bruchinae). In the present study, 
using scanning electron microscopy, we observed subtle differences in integument texture among the tested genotypes (Fig. 1). However, the extent to which these differences affect insect behavior remains unknown, and it is not possible to affirm that stronger or weaker oviposition preference of $Z$. subfasciatus for the studied genotypes can be attributed to these differences in grain integument.

Among the assessed genotypes, accessions IAC 583, IAC 584, IAC 816, IAC 818, and IAC 819 contain arcelin, a protein in the lectin family (Chrispeels 1997), toxic to many insects, including Z. subfasciatus (Mazzonetto and Vendramim 2002; Eduardo et al. 2016). Lara (1997) observed a weaker attraction of adult $Z$. subfasciatus for certain genotypes of $P$. vulgaris that contain arcelin when compared to other genotypes without this protein, in a free-choice test. However, these arcelin-free genotypes were not the same as those used in the present study, in which lower attraction may be associated with factors other than arcelin presence. If an insect is able to detect lectins or arcelins during a test-bite, it might also be able to recognize and discriminate among plants that contain the protein and those that do not (Vendramim and Guzzo 2009). Such behavior has already been reported for Nilaparvata lugens (Stål) (Hemiptera: Delphacidae) in regard to the lectin of Galanthus nivalis (L.) (Foissac et al. 2000), but this is unlikely to be the case for Z. subfasciatus, as adult bruchids do not feed (Lawrence et al. 1991; Athié and Paula 2002; Hill 2002).

Lara (1997) and Wanderley et al. (1997) also conducted free-choice tests including arcelincontaining genotypes and observed that these genotypes were among the most oviposited, with similar results to those obtained in the present study. Our results are also similar to the findings of RibeiroCosta et al. (2007), who observed no difference between 'Bolinha' and other tested genotypes (including those containing arcelin) with respect to oviposition by $Z$. subfasciatus. In no-choice tests, genotypes containing arcelin have not been less oviposited than others without that protein (Lara 1997; Wanderley et al. 1997; Mazzonetto and Vendramim 2002), corroborating the findings of the present study.
Fig. 1 Scanning electron micrograph of coat surface of grains of different genotypes of common bean Phaseolus vulgaris. $\mathrm{a}=$ accession IAC 853; $\mathrm{b}-\mathrm{c}=$ accession IAC 610; $\mathrm{d}=$ accession IAC 583. Bars $=10 \mu \mathrm{m}$
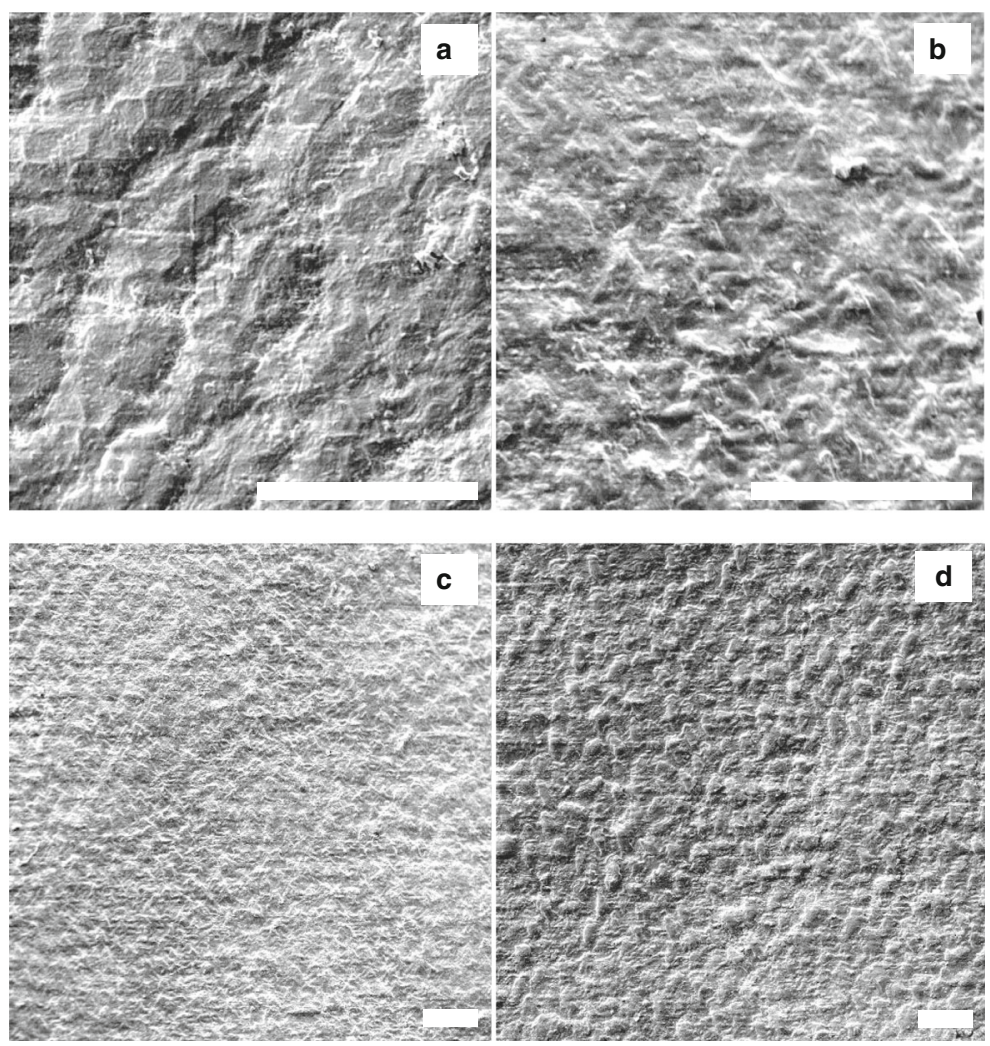
As shown by Paes et al. (2000), the toxic activity of an arcelin on $Z$. subfasciatus involves its binding to the digestive tract of the insect, rupturing it and penetrating the hemocele, which means that an arcelin can only act after it has been ingested by the insect larva. The arcelincontaining lineages of $P$. vulgaris that are commonly used in pest resistance tests are normally obtained by crossing a cultivar with a wild genotype that carries the protein. For example, Pereira et al. (1995) and Barbosa et al. (1999, 2000a, 2000b, 2002) obtained their materials by crossing wild genotypes containing the variants arcelin-1 to arcelin4 with the cultivar Porrillo 70. Eduardo et al. (2016) also tested bean genotypes derived from arcelin-containing parentals. It can therefore be assumed that host selection by $Z$. subfasciatus among arcelin-containing genotypes of $P$. vulgaris is influenced more strongly by other characteristics of the cultivars that were crossed to obtain these genotypes than by the presence of arcelin.

The lower number of eggs laid on IAC 853 under freechoice conditions may be interpreted as an indication of antixenosis. However, this non-preference for IAC 853 was not observed during no-choice testing. No-choice testing is a more accurate reflection of the conditions found in warehouses and rural properties, where normally a single cultivar of beans is stored in large amounts, and therefore we cannot affirm that IAC 853 is resistant to Z. subfasciatus.

In conclusion, the results obtained in this study indicate that genotype IAC 853 cannot be characterized as resistant to Z. subfasciatus, even though it was less oviposited during free-choice testing; and arcelin does not appear to influence in host selection by $Z$. subfasciatus, despite its toxicity to insects. These findings advance existing knowledge and are important for consideration within genetic improvement programs focusing on pest resistance by bean crops.

Acknowledgments Authors are grateful to Conselho Nacional de Desenvolvimento Científico e Tecnológico (CNPq) and Coordenação de Aperfeiçoamento de Pessoal de Nível Superior (CAPES) for fellowships; to Dr. João Gomes da Costa, for assisting with the statistical analyses; and to Dr. Elliot Watanabe Kitajima, for providing training and access to electron microscopy equipment.

\section{Compliance with ethical standards}

Conflict of interest The authors declare that they have no conflict of interest. The corresponding author has received a scholarship from the Brazilian agency Coordenação de Aperfeiçoamento de Pessoal de Nível Superior (CAPES).

\section{References}

Athié, I., \& Paula, D. C. (2002). Insetos de grãos armazenados: Aspectos biológicos e identificação (2nd ed.). São Paulo: Livraria Varela.

Baldin, E. L. L., \& Pereira, J. M. (2010). Resistência de genótipos de feijoeiro a Zabrotes subfasciatus (Bohemann, 1833) (Coleoptera: Bruchidae). Ciência e Agrotecnologia, 34(6), $1507-1513$

Baldin, E. L. L., Franco, R. S. R., \& Souza, D. R. (2007). Resisténcia de genótipos de feijoeiro Phaseolus vulgaris (L.) a Zabrotes subfasciatus (Boh., 1833) (Coleoptera: Bruchidae). Boletín de Sanidad Vegetal. Plagas, 33, 369375.

Barbosa, F. R., Yokoyama, M., Pereira, P. A. A., \& Zimmermann, F. J. P. (1999). Efeito da proteína arcelina na biologia de Zabrotes subfasciatus (Boheman, 1833), em feijoeiro. Pesquisa Agropecuária Brasileira, 34(10), 1805-1810.

Barbosa, F. R., Yokoyama, M., Pereira, P. A. A., \& Zimmermann, F. J. P. (2000a). Danos de Zabrotes subfasciatus (Boh.) (Coleoptera: Bruchidae) em linhagens de feijoeiro (Phaseolus vulgaris L.) contendo arcelina. Anais da Sociedade Entomológica do Brasil, 29(1), 113-121.

Barbosa, F. R., Yokoyama, M., Pereira, P. A. A., \& Zimmermann, F. J. P. (2000b). Estabilidade da resistência a Zabrotes subfasciatus conferida pela proteína arcelina, em feijoeiro. Pesquisa Agropecuária Brasileira, 35(5), 895-900.

Barbosa, F. R., Yokoyama, M., Pereira, P. A. A., \& Zimmermann, F. J. P. (2002). Controle do caruncho-do-feijoeiro Zabrotes subfasciatus com óleos vegetais, munha, materiais inertes e malathion. Pesquisa Agropecuária Brasileira, 37(9), 12131217.

Bastos, J. A. M. (1969). Repelência em feijão mulatinho (Phaseolus vulgaris L.) ao gorgulho Callosobruchus analis Fabr. (Bruchidae: Coleoptera). Pesquisa Agropecuária Brasileira, 4(1), 123-126.

Bernays, E. A., \& Chapman, R. F. (1994). Host-plant selection by phytophagous insects. New York: Chapman \& Hall.

Boiça Jr., A. L., Botelho, A. C. G., \& Toscano, L. C. (2002). Comportamento de genótipos de feijoeiro ao ataque de Zabrotes subfasciatus (Boheman, 1833) (Coleoptera: Bruchidae) em condições de laboratório. Arquivos do Instituto Biológico, 69(1), 51-55.

Brasil (2006). Instrução normativa No. 25, de 23 de maio de 2006. Estabelece os critérios mínimos a serem observados para a determinação do valor de cultivo e uso - VCU de feijão e os respectivos formulários anexos para inscrição de cultivares no Registro Nacional de Cultivares. Brasília: Diário Oficial, 19 Jun. Section 1, p. 16.

Chrispeels, M. J. (1997). Transfer of bruchid resistance from the common bean to other starchy grain legumes by genetic engineering with the $\alpha$-amylase inhibitor gene. In $\mathrm{N}$. Carozzi \& M. Koziel (Eds.), Advances in insect control: The role of transgenic plants (pp. 139-156). London: Taylor \& Francis.

Cruz, C. D. (2013). GENES - a software package for analysis in experimental statistics and quantitative genetics. Acta Scientiarum. Agronomy, 35(3), 271-276. 
Cruz, C. D. (2016). Genes software - Extended and integrated with the R, Matlab and Selegen. Acta Scientiarum. Agronomy, 38(4), 547-552.

Eduardo, W. I., Boiça Júnior, A. L., Moraes, R. F. O., Chiorato, A. F., Perlatti, B., \& Forim, M. R. (2016). Antibiosis levels of common bean genotypes toward Zabrotes subfasciatus (Boheman) (Coleoptera: Bruchidae) and its correlation with flavonoids. Journal of Stored Products Research, 67, 63-70.

Foissac, X., Loc, N. T., Christou, P., Gatehouse, A. M. R., \& Gatehouse, J. A. (2000). Resistance to green leafhopper (Nephotettix virescens) and brown planthopper (Nilaparvata lugens) in transgenic rice expressing snowdrop lectin (Galanthus nivalis agglutinin; GNA). Journal of Insect Physiology, 46(4), 573-583.

Guzzo, E. C., Vendramim, J. D., Chiorato, A. F., Lourenção, A. L., Carbonell, S. A. M., \& Corrêa, O. M. B. (2015). No correlation of morpho-agronomic traits of Phaseolus vulgaris (Fabaceae) genotypes and resistance to Acanthoscelides obtectus (say) and Zabrotes subfasciatus (Boheman) (Coleoptera: Chrysomelidae). Neotropical Entomology, 44(6), 619-625.

Hill, D. S. (2002). Pests: Class Insecta. In D. S. Hill (Ed.), Pests of stored foodstuffs and their control (pp. 135-315). Secaucus: Kluwer Academic Publishers.

Lara, F. M. (1997). Resistance of wild and near isogenic bean lines with arcelin variants to Zabrotes subfasciatus (Boheman). I winter crop. Anais da Sociedade Entomológica do Brasil, 26(3), 551-560.

Lawrence, J. F., Anderson, D. M., Beal Jr., R. S., Becker, E. C., Bell, R. T., Bousquet, Y., Bright, D. E., Brown, H. P., Carlson, D. C., Cooper, K. W., Dogger, J. R., Dybas, H. S., Foster, D. E., Frank, J. H., Kavanaugh, D. H., Labella, D. M., Lawson, F. A., Lesage, L., Lloyd, J. E., Newton Jr., A. F., Pfaffenberger, G. S., Reichardt, H., Selander, R. B., Spangler, P. J., Spilman, T. J., De Viedma, M. G., Wheeler, Q. D., \& Young, D. K. (1991). Order Coleoptera. In F. W. Stehr (Ed.), Immature insects (pp. 144-658). Dubuque: Kendall/Hunt Publishing.

Mazzonetto, F., \& Boiça Jr., A. L. (1999). Determinação dos tipos de resistência de genótipos de feijoeiro ao ataque de Zabrotes subfasciatus (Boh.) (Coleoptera: Bruchidae). Anais da Sociedade Entomológica do Brasil, 28(2), 307-311.

Mazzonetto, F., \& Vendramim, J. D. (2002). Aspectos biológicos de Zabrotes subfasciatus (Boh.) (Coleoptera: Bruchidae) em genótipos de feijoeiro com e sem arcelina. Neotropical Entomology, 31(3), 435-439.

Moraes, C. P. B., Boiça Jr., A. L., Souza, J. R., \& Costa, J. T. (2011). Determinação dos tipos de resistência em genótipos de feijoeiro ao ataque de Zabrotes subfasciatus (Coleoptera: Bruchidae). Revista Ceres, 58(4), 419-424.

Norris, R. F., Caswell-Chen, E. P., \& Kogan, M. (2003). Concepts in integrated pest management. Upper Saddle River: Prentice Hall.
Nwanze, K. F., \& Horber, E. (1976). Seed coats of cowpeas affect oviposition and larval development of Callosobruchus maculatus. Environmental Entomology, 5(2), 213-218.

Nwanze, K. F., Horber, E., \& Pitts, C. W. (1975). Evidence for ovipositional preference of Callosobruchus maculatus. Environmental Entomology, 4(3), 409-412.

Paes, N. S., Gerhardt, I. R., Coutinho, M. V., Yokoyama, M., Santana, E., Harris, N., Chrispeels, M. J., \& Grossi de Sa, M. F. (2000). The effect of arcelin-1 on the structure of the midgut of bruchid larvae and immunolocalization of the arcelin protein. Journal of Insect Physiology, 46(4), 393-402.

Panda, N., \& Khush, G. S. (1995). Host plant resistance to insects. Wallingford: CAB International.

Parsons, D. M. J., \& Credland, P. F. (2003). Determinants of oviposition in Acanthoscelides obtectus: A nonconformist bruchid. Physiological Entomology, 28(3), 221-231.

Pereira, P. A. A., Yokoyama, M., Quintela, E. D., \& Bliss, F. A. (1995). Controle do caruncho Zabrotes subfasciatus (Boheman, 1833) (Coleoptera: Bruchidae) pelo uso de proteína da semente em linhagens quase isogênicas de feijoeiro. Pesquisa Agropecuária Brasileira, 30(8), 10311034.

Ramalho, M. A. P., Botelho, W., \& Salgado, L. O. (1977). Comportamento de algumas variedades de feijão (Phaseolus vulgaris, L) quanto a suscetibilidade ao caruncho Acanthoscelides obtectus (Say, 1831). Anais da Sociedade Entomológica do Brasil, 6(2), 243-250.

Ribeiro-Costa, C. S., Pereira, P. R. V. S., \& Zukovski, L. (2007). Desenvolvimento de Zabrotes subfasciatus (Boh.) (Coleoptera: Chrysomelidae, Bruchinae) em genótipos de Phaseolus vulgaris L. (Fabaceae) cultivados no Estado do Paraná e contendo arcelina. Neotropical Entomology, 36(4), 560-564.

Silva, A. G, d' A., Gonçalves, C. R., Galvão, D. M., Gonçalves, A. J. L., Gomes, J., Silva, M. N., \& Simoni, L. (1968). Quarto catálogo dos insetos que vivem nas plantas do Brasil: Seus parasitos e predadores. Rio de Janeiro: Laboratório Central de Patologia Vegetal.

Smith, C. M. (2005). Plant resistance to arthropods: Molecular and conventional approaches. Berlin: Springer.

Vendramim, J. D., \& Guzzo, E. C. (2009). Resistência de plantas e a bioecologia e nutrição dos insetos. In A. R. Panizzi \& J. R. P. Parra (Eds.), Bioecologia e nutrição de insetos: Base para o manejo integrado de pragas (pp. 1055-1105). Brasília: Embrapa Informação Tecnológica.

Vendramim, J. D., \& Guzzo, E. C. (2012). Plant resistance and insect bioecology and nutrition. In A. R. Panizzi \& J. R. P. Parra (Eds.), Insect bioecology and nutrition for integrated pest management (pp. 657-685). Boca Raton: CRC Press.

Wanderley, V. S., Oliveira, J. V., \& Andrade Jr., M. L. (1997). Resistência de cultivares e linhagens de Phaseolus vulgaris L. a Zabrotes subfasciatus (Boh.) (Coleoptera: Bruchidae). Anais da Sociedade Entomológica do Brasil, 26(2), 315320 . 